\title{
Perceived Stress Levels in Pakistani Dental Students During COVID-19 Lockdown
}

\author{
Hina Zafar Raja, Muhammad Nasir Saleem, Tayyaba Saleem, Haroon Rashid, Saroosh Ehsan, \\ Saman Hakeem, and Asif Hanif
}

\section{ABSTRACT}

Objective: The objective of this study is to assess the stress levels of Pakistani dental students through an established stress assessment tool during lockdown for COVID-19 pandemic.

Materials and methods: A cross-sectional quantitative study using a selfadministered, voluntarily filled online questionnaire was conducted on undergraduate dental students from first to fourth (Final) years of dental institutes across Pakistan, accredited by the Pakistan Medical \& Dental Council (PMDC). Study questionnaire contained questions on demographic details; gender, province of college, province of residence and perceived stress scale of 10 questions. It also contained questions about the presence of any symptoms relevant to a particular type of stress. i.e. emotional stress, physical (body related) stress, behavioral stress and cognitive stress. Descriptive statistics were calculated for gender, residence of participants, location of institutes, levels of stress and symptoms signifying a particular stress type. Multiple variables of each stress type were compared with categories of perceived stress scores using chi square test.

Results: 706 dental students responded. 53.5\% were going through high stress levels, $\mathbf{4 3 . 4 \%}$ were going through moderate stress levels while $\mathbf{2 . 9 \%}$ were having low stress levels. Majority of the participants with moderate and high stress levels were from institutions located in provinces with increased number of COVID-19 positive cases. Among moderate and highly stressed participants, more than $68 \%$ were females. A significant number of dental students reported symptoms pertaining to emotional, physical, cognitive and behavioral stress due to the COVID-19 disease.

Conclusion: Majority of Pakistani dental students are suffering from moderate to high stress levels specially in provinces with a higher number of COVID-19 affected reported cases. There are considerable effects on emotional, physical, cognitive and behavioral states of Pakistani dental students due to the spread of this disease.

Keywords: Students, Dental; Stress, Psychological; Pandemics; Infections; Academies and Institutes.
Published Online: July 30, 2020

ISSN: $2684-4443$

DOI :10.24018/ejdent.2020.1.4.14

Hina Zafar Raja *

Professor, Institute of Dentistry, CMH

Lahore Medical College, Lahore, NUMS, Pakistan.

(e-mail: hinazafarraja@gmail.com)

Muhammad Nasir Saleem

Professor, Institute of Dentistry, CMH

Lahore Medical College, Lahore, NUMS, Pakistan.

(e-mail: cavaldent@gmail.com)

Tayyaba Saleem

Professor, Islamabad Medical and Dental College, Pakistan.

(e-mail: drtayyabasaleem@ gmail.com) Haroon Rashid

Vice Principal and Deputy Chief Executive, CMH Medical Lahore College and Institute of Dentistry, Lahore, NUMS, Pakistan.

(e-mail: drharoon10@gmail.com) Saroosh Ehsan

Fatima Memorial College of Medicine and Dentistry, Lahore, Pakistan. (e-mail: sarooshehsan77@gmail.com) Saman Hakeem

Professor, Bahria University Medical and Dental college, Karachi, Pakistan. (e-mail: samanharain@gmail.com) Asif Hanif

Biostatistics Unit - University Institute of Public Health, Pakistan.

(e-mail: mebiostatistician ${ }^{\circledR}$ gmail.com)

*Corresponding Author

\section{INTRODUCTION}

The pandemic of corona virus disease caused by an enveloped virus COVID-19 is gradually engulfing the whole world. Its spread is exponential, however the mortality rate is $2 \%$ [1]. Corona virus can transmit via respiratory droplets, saliva, nasal droplets, direct contact of surfaces or indirect contact (fomites) transmission [2]. The incubation period varies from 4-14 days [3]. The virus can survive on metal and plastic surfaces for more than 48 hours and clinically presents as an upper respiratory tract infection, dry cough, high grade fever and/or dyspnea [4]. Treatment protocols are still being formulated. To date, the recovery of affected individuals may depend upon a person's immune response [5]. In order to minimize infection transmission, all social contacts worldwide are reduced through lockdown. Lockdown is an emergency restrictive measure during a threat or danger [6]. Around 150 countries including Pakistan has closed all general and health related academies, institutes and social networks at various levels.

Due to close exposure to aerosols and infected droplets from patient's oral cavity, dentists are at a higher risk of acquiring and spreading the disease [7]. The situation is mentally challenging for dental practitioners, teaching faculty and dental professional students. Online teaching has replaced face to face teaching. Travel restrictions during lock down and feeling of home sickness within international 
students and impending fear of mortality may lead to emotional stress [8]. Furthermore, dental students also undergo academic stress (fear of inability to comprehend the desired knowledge in due time, or the burden of increased content of curriculum) and professional stress (fear of making poor choice of profession, lack of professional progress, or fear of inability to earn in future). Stress is a positive or negative body reaction to physical, emotional or mental stimuli. It is generated when a person appraises any situation imperiling to his or her resources or general wellbeing [9]. Stress perception may depend upon the personality type, existing support system and environment of the individual [10]. It has a physical and a psychological component [11]. Dental students have to face additional challenges of grooming of interpersonal skills and achievement of manual expertise [12]. The response of health care students to such critical situations may vary from self-contained anxiety to suicidal attempts [13], [14]. Similar results were found in Pakistani health care students [15]. It is logical to assess the extent of stress of affected individuals.

Various tools are utilized to assess the stress of individuals. Amongst them, Perceived stress is a widely used psychological instrument scale to establish the grade and nature of stress of an individual [16]. It evaluates the perception of an individual to stressful and uncontrollable situations happening during past one month [17]. It is a measure of perception of academic and professional stress of medical students during their normal course of undergraduate training, including Pakistan [18]. In addition, the effects of stress on physical and psychological health should also be considered [19]. The rationale of this study is to determine the degree and type of stress found in Pakistani dental students during the spread of COVID-19 pandemic. This will aid in establishing effective planning for stress management during the time of such crisis. The objective of this study is to assess the stress levels of Pakistani dental students through an established stress assessment tool during lockdown for COVID-19 pandemic. It was hypothesized that the students will have higher stress scores in the present situation.

\section{MATERIALS AND METHODS}

It was a cross-sectional quantitative study using a selfadministered, voluntarily filled online questionnaire. The survey was conducted on undergraduate dental students from first to fourth (Final) years of dental institutes across Pakistan, accredited by the Pakistan Medical \& Dental Council (PMDC). The study conforms to STROBE guidelines for cross sectional studies. Colleges with inaccessible administrations and students through email or WhatsApp were excluded. 385 sample size was calculated by using WHO formula [20], with $95 \%$ confidence and $5 \%$ margin of error. Census sampling (All students from all classes included) was done. The questionnaire was shared in two colleges of each of four provinces of Pakistan, and two colleges located in federal capital, Islamabad. The study duration was one month, from April 2020 to May 2020. In total, 706 dental students responded, with a response rate of $35 \%$. The response rate was improved with prior notifications through a text message on their smart phones, and then an official e mail was sent for completion of form. However, the fear of exposure, penalization of participating students and forceful filling by authorities was addressed by reassurance of anonymity. An average student took approximately 3 minutes to fill in the form. There was no missing data, as software did not allow incomplete forms to be submitted.

Study questionnaire was designed in English language, as an online form accessible from the link https://www.surveymonkey.com/r/83D9XCG. It contained questions on demographic details; gender, province of college and province of residence. The title of questionnaire as well as all questions of PSS-10 inquired the stress states of participants pertaining to lockdown. The purpose of the study was initially explained. All students were asked to read the instructions on top of the form carefully before starting to fill in the forms.

The internal reliability of PSS-10 was reported as $>0.78$ for psychometric assessment in Pakistani population [21]. The test-retest reliability of this tool was also reported as $>0.70$ [17]. All questions bear a maximum score of four making the cumulative score to be 40. A PSS score of 0-13 was considered low, 14-26 moderate and 27-40 as high perceived stress score. The variable of interest was, "Student stress level".

The second part of the survey form contained questions about the presence of any physical symptoms relevant to a particular type of stress. i.e. emotional stress, physical (body related) stress, behavioral stress and cognitive stress [19] (Table 1). The reliability of second part of questionnaire was calculated by Cronbach's alpha as 0.71. Frequency distribution of physical symptoms were calculated to evaluate their prevalence in low, moderate and high stressed dental students. The questionnaire was validated by five senior members of experts from different institutions. They assessed all items of the questionnaire on the basis of relevance, content, language and cultural acceptance for Pakistani students. The responses from all 5 faculty members were analyzed and adjusted, for internal validity.

Permission was granted from institutional review boards. Students of all four classes were approached through official emails.

The data were entered in SPSS. Descriptive statistics were applied for socio-demographic variables. The frequencies and percentages were calculated for gender, residence of participants, location of institutes, and levels of stress. Demographic and symptomatic variables of each stress type were compared with low, moderate and high perceived stress scores using chi square test. The $\mathrm{p}$ value was considered significant, if $\leq 0.05$.

\section{RESUlTS}

The results of our study showed that $73.8 \%$ of total respondents were females, while $26.2 \%$ were males.

The provincial residential distribution of participants across Pakistan showed 53.5\% residents from Punjab and $19.4 \%$ from Sindh. Institutional location showed maximum participation from Punjab $(41.9 \%)$ followed by Sindh (29.8\%), Islamabad (22.9\%) and Balochistan (0.5\%). 
Perceived stress scale showed that out of 706 respondents, $53.5 \%$ were going through high stress levels, $43.4 \%$ were going through moderate stress levels while $2.9 \%$ were having low stress levels. Total mean PSS score was 26.3 (Fig. 1).

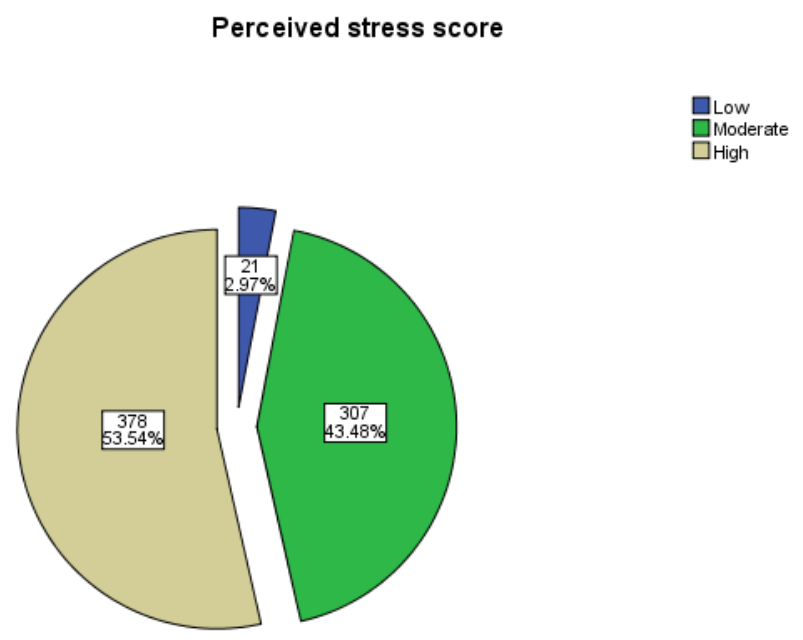

Fig. 1. Perceived stress scores for participants of survey of Pakistani dental students during COVID-19 lockdown.

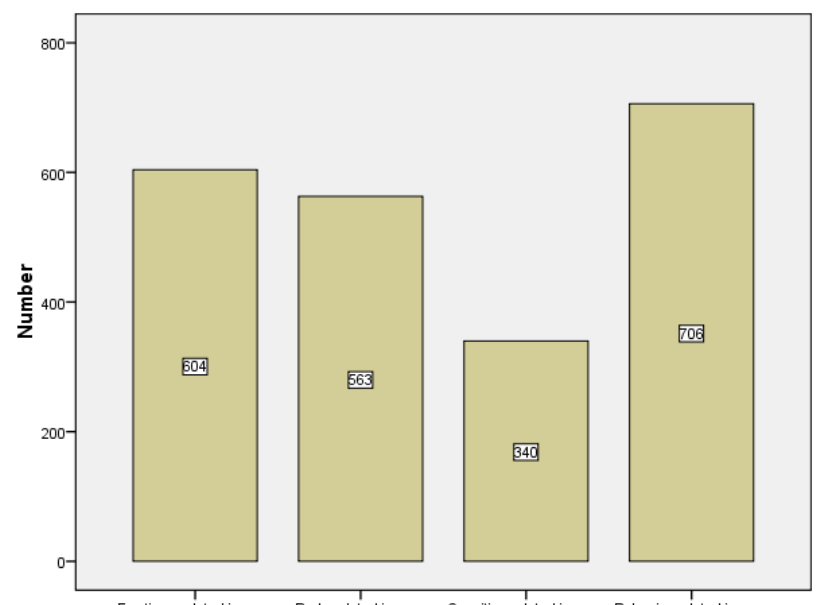

Emotions related issues Body related issues Cognition related issues Behavior related issues
Fig. 2. Number of Pakistani dental students reporting presence o any symptom [19] pertaining to Emotional, Physical (Body related), Cognitive and Behavioral stresses during COVID-19 lockdown.

The second part of questionnaire inquired about the presence of any symptom pertaining to emotional, physical (body related), cognitive and behavioral stresses (Fig. 2) [19]. This depicted marked overlapping of symptoms, with prominent dominance of behavior related issues as, they were reported by all 706 participants $(100 \%)$. Emotional and physical issues were also prominent in 604(85\%) and 563 $(79 \%)$ participants respectively, while $340 \quad(48 \%)$ participants showed cognitive difficulties.

Frequencies of symptoms representing a specific stress type is given in Table 1.

In emotion related issues, out of 604 respondents, $49.1 \%$ presented with agitated frustrated behavior followed by feeling depressed, difficulty in relaxing, avoiding others and losing control respectively. $15.4 \%$ reported no symptom.

In physical (body related) issues, out of 563 respondents,54.8\% reported having low energy. Rest complained of headaches, insomnia and jaw clenching/ grinding, while $21.8 \%$ did not feel any of these symptoms.
In behavior related issues, $66.7 \%$ of 706 were feeling angry, followed by change in appetite up to $53.8 \%$. In cognition related issues, out of 340 , forgetfulness and disorganization were reported by $56.6 \%$ followed by constant worrying, racing thoughts, pessimistic thinking and inability to focus.

TABLE 1: FREQUENCY DISTRIBUTION OF SYMPTOMS PERTAINING TO EMOTIONAL, PHYSICAL (BODY RELATED), COGNITIVE AND BEHAVIORAL STRESSES REPORTED BY PAKISTANI DENTAL STUDENTS DURING COVID-19 LOCKDOWN

\begin{tabular}{|c|c|c|c|}
\hline & & No. of cases & Percent \\
\hline \multirow{6}{*}{$\begin{array}{l}\text { Emotions } \\
\text { related } \\
\text { issues }\end{array}$} & $\begin{array}{l}\text { Becoming easily agitated, frustrated, } \\
\text { and moody }\end{array}$ & 325 & $49.1 \%$ \\
\hline & $\begin{array}{l}\text { Feeling overwhelmed, like you are } \\
\text { losing control or need to take control }\end{array}$ & 168 & $25.4 \%$ \\
\hline & $\begin{array}{l}\text { Having difficulty relaxing and } \\
\text { quieting your mind }\end{array}$ & 223 & $33.7 \%$ \\
\hline & $\begin{array}{l}\text { Feeling bad about yourself (low self- } \\
\text { esteem), lonely, worthless, and } \\
\text { depressed. }\end{array}$ & 251 & $37.9 \%$ \\
\hline & Avoiding others & 201 & $30.4 \%$ \\
\hline & None of the above & 102 & $15.4 \%$ \\
\hline \multirow{6}{*}{$\begin{array}{c}\text { Body related } \\
\text { issues }\end{array}$} & Low energy & 359 & $54.8 \%$ \\
\hline & Headaches & 234 & $35.7 \%$ \\
\hline & Insomnia & 211 & $32.2 \%$ \\
\hline & Clenched jaw and grinding teeth & 82 & $12.5 \%$ \\
\hline & dry mouth and difficulty swallowing & 0 & $0 \%$ \\
\hline & None of the above & 143 & $21.8 \%$ \\
\hline \multirow{6}{*}{$\begin{array}{l}\text { Cognition } \\
\text { related } \\
\text { issues }\end{array}$} & Constant worrying & 224 & $34.1 \%$ \\
\hline & Racing thoughts & 213 & $32.4 \%$ \\
\hline & Forgetfulness and disorganization & 372 & $56.6 \%$ \\
\hline & Inability to focus & 121 & $18.4 \%$ \\
\hline & $\begin{array}{l}\text { Being pessimistic or seeing only the } \\
\text { negative side }\end{array}$ & 133 & $20.2 \%$ \\
\hline & None of the above & 366 & $55.7 \%$ \\
\hline \multirow{6}{*}{$\begin{array}{l}\text { Behavior } \\
\text { related } \\
\text { issues }\end{array}$} & $\begin{array}{l}\text { Changes in appetite -- either not eating } \\
\text { or eating too much }\end{array}$ & 225 & $53.8 \%$ \\
\hline & Feeling angry & 279 & $66.7 \%$ \\
\hline & $\begin{array}{l}\text { Procrastinating and avoiding } \\
\text { responsibilities }\end{array}$ & 24 & $5.7 \%$ \\
\hline & $\begin{array}{l}\text { Increased use of alcohol, drugs, or } \\
\text { cigarettes }\end{array}$ & 80 & $19.1 \%$ \\
\hline & $\begin{array}{l}\text { Exhibiting more nervous behaviors } \\
\text { such as nail biting, fidgeting, pacing } \\
\text { and. }\end{array}$ & 0 & $0 \%$ \\
\hline & None of the above & 0 & $0 \%$ \\
\hline
\end{tabular}

Table 2 shows comparison of demographical variables and perceived stress scores. In moderate and high stress levels, females show a significantly greater number of $68 \%$ and $79.4 \%$ respectively. The $\mathrm{p}$ value was calculated as 0.001 .

Low, moderate and high stress levels did not differ significantly in four provinces of Pakistan as well as federal capital, pertaining to the students belonging to these areas. However, the levels of stress did differ in the provinces where institutions were located. $45 \%$ of moderately stressed participants were from institutions of Punjab province, while 28.3\% were from institutions in Sindh province. $40 \%$ of highly stressed individuals were studying in Punjab and $31.5 \%$ of them were in Sindh. The $\mathrm{p}$ value for institutional comparison was calculated as 0.001 . 
TABLE 2: COMPARISON OF DEMOGRAPHICAL VARIABLES AND PERCEIVED STRESS SCORES

\begin{tabular}{|c|c|c|c|c|c|}
\hline & & \multicolumn{3}{|c|}{ Perceived stress score } & \multirow{2}{*}{$\begin{array}{c}\text { Chi- } \\
\text { square } \\
\text { (p-value) }\end{array}$} \\
\hline & & Low & Moderate & High & \\
\hline \multirow{2}{*}{ Gender } & Male & $11(52.4 \%)$ & $96(31.3 \%)$ & $78(20.6 \%)$ & \multirow{2}{*}{$\begin{array}{c}17.579 \\
(<0.001 * *)\end{array}$} \\
\hline & Female & $10(47.6 \%)$ & $211(68.7 \%)$ & $300(79.4 \%)$ & \\
\hline \multirow{5}{*}{$\begin{array}{c}\text { Province of } \\
\text { Residence }\end{array}$} & $\begin{array}{c}\text { Islamabad } \\
\text { (Federal) }\end{array}$ & $3(14.3 \%)$ & $42(13.7 \%)$ & $67(17.7 \%)$ & \multirow{5}{*}{$\begin{array}{c}6.052 \\
(0.641)\end{array}$} \\
\hline & Punjab & $11(52.4 \%)$ & $171(55.7 \%)$ & $196(51.9 \%)$ & \\
\hline & KPK & $2(9.5 \%)$ & $25(8.1 \%)$ & $32(8.5 \%)$ & \\
\hline & Sindh & $3(14.3 \%)$ & $61(19.9 \%)$ & $73(19.3 \%)$ & \\
\hline & Baluchistan & $2(9.5 \%)$ & $8(2.6 \%)$ & $10(2.6 \%)$ & \\
\hline \multirow{5}{*}{$\begin{array}{c}\text { Province } \\
\text { where your } \\
\text { institution is } \\
\text { situated }\end{array}$} & $\begin{array}{c}\text { Islamabad } \\
\text { (Federal) }\end{array}$ & $7(33.3 \%)$ & $67(21.8 \%)$ & $88(23.3 \%)$ & \multirow{5}{*}{$\begin{array}{c}35.976 \\
(<0.001 * *)\end{array}$} \\
\hline & Punjab & $6(28.6 \%)$ & $138(45 \%)$ & $152(40.2 \%)$ & \\
\hline & KPK & $1(4.8 \%)$ & $13(4.2 \%)$ & $19(5 \%)$ & \\
\hline & Sindh & $5(23.8 \%)$ & $87(28.3 \%)$ & $119(31.5 \%)$ & \\
\hline & Baluchistan & $2(9.5 \%)$ & $2(0.7 \%)$ & $0(0 \%)$ & \\
\hline
\end{tabular}

Table 3 shows the comparison of multiple variables with low, medium and high categories of perceived stress scores. More than $80 \%$ of moderate and highly stressed individuals did report any one complaint regarding emotion related issues. The $\mathrm{p}$ value was calculated as 0.001 . In body related issues, approximately $50 \%$ of moderate and severely stressed individuals were showing low energy levels. The $p$ value was 0.008 . More than $78 \%$ of them did show any such complaint. The $\mathrm{p}$ value was $<0.001$. Regarding cognitive skills, more than $50 \%$ of moderate and highly stressed participants agreed to forgetfulness and disorganization. Constant worrying, racing thoughts, inability to focus or pessimism were present in all stress categories. There was significant difference in behavior related issues of each category of perceived stress scores.

\section{DISCUSSION}

Perceived stress scale is a convenient, brief tool to measure psychological stress, allowing inclusion of additional tools within same research. During the spread of COVID-19 pandemic, it is important for universities to assess the stress levels of students for their apt counselling and provision of mental health support [22]. The results of this study conformed to hypothesis. More than $50 \%$ of participants $(53.5 \%)$ were going through high stress levels, while $43.4 \%$ were having moderate stress levels. However, the mean PSS score was between moderate to high levels. Mean score may not differ much from studies done in normal circumstances, on medical students of Pakistan. [18], [23]. Thus psychological, social and academic stressors may collectively also contribute to this score.

Increased stress level can be associated with negative outcomes like depression [24]. PSS possess a satisfactory relation with depression and anxiety [17\], which implicates its utilization in assessment of an individual's stress levels. This indicates the value of PSS in stress judgement during the COVID-19 pandemic outbreak. $73.8 \%$ participants of this study were females. Presence of more females in a population may explain the possible reason for increased stress scores in that population [9], [25], [26]. However, other studies did not show such gender discrimination [27], [28]. A possible explanation can be presence of varied ethnicity and area of belonging of dental students can affect the outcome of results.

Students of institutes located in Punjab and Sindh presented with a significantly higher stress levels than other provinces. A possible reason for this can be the significantly increased in numbers of COVID-19 affected people in Punjab and Sindh, as compare to other areas of Pakistan [29]. The fear of greater chances of acquiring infection from their work place i.e. their institutes, may affect the stress levels of these students [7].

Higher stress levels denotes student's response in a stressful condition. Low stress levels may indicate a positive response and his ability to cope well in difficult situations [22]. Feeling of self control over stressor may improve an individual's response to stress. Results signify the gravity of situation and agrees with other studies utilizing multiple questionnaires, anxiety scales and severity indices to indicate stress levels during COVID-19 outbreak [30], [31]. The difference in stress levels of people living in similar situation depends upon their stress coping capabilities.

This study also explained the effects of pandemic stress on well being of dental students. A stressor may have variable effects on health status of an individual. During stress, cortisol is released to make energy accessible to heart and brain. Simultaneous activation of limbic system with hypothalamic-adrenal-pituitary axis result in release of adrenaline. This initiates immediate cardiovascular and metabolic response. Prefrontal cortex stimulates stress pathways of hypothalamus and brainstem through amygdala to regulate emotions. An acute phase may show improved emotional response through amygdala [32]. If the stress persists for a longer time period, then the inhibition of immediate response is suppressed. The level of stress mediators remains high in blood causing damage to multiple organ and tissues.

Stress reduces high order prefrontal cortex functioning of cognition, due to poor synaptic connections, which is evident in the present study [33]. Altered release of noradrenaline and dopamine may negatively affect the working memory of brain [32]. Dorsolateral aspect of prefrontal cortex connects to sensory, motor cortices for behavior regulation and bodily responses. Immune responses, growth and reproduction are impeded due to chronic stress, as cortisol concurrently occupies all kinds of its receptors in brain, leading to variable effects on all systems of the body [34]. 
TABLE 3: COMPARISONS OF MULTIPLE VARIABLES IN PERCEIVED STRESS SCORE

\begin{tabular}{|c|c|c|c|c|c|c|}
\hline & & & \multicolumn{3}{|c|}{ Perceived stress score } & \multirow{2}{*}{$\begin{array}{c}\text { Chi-square } \\
\text { (p-value) }\end{array}$} \\
\hline & & & Low & Moderate & High & \\
\hline \multirow{12}{*}{ 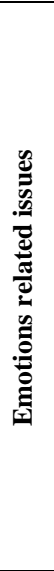 } & \multirow{2}{*}{$\begin{array}{l}\text { Becoming easily agitated, } \\
\text { frustrated, and moody }\end{array}$} & Yes & $9(42.9 \%)$ & $141(45.9 \%)$ & $175(46.3 \%$ & \multirow{2}{*}{$\begin{array}{c}0.097 \\
(0.953) \\
\end{array}$} \\
\hline & & No & $12(57.1 \%)$ & $166(54.1 \%)$ & $203(53.7 \%)$ & \\
\hline & \multirow{2}{*}{$\begin{array}{c}\text { Feeling overwhelmed, like you } \\
\text { are losing control or need to } \\
\text { take control }\end{array}$} & Yes & $1(4.8 \%)$ & $80(26.1 \%)$ & $87(23 \%)$ & \multirow{2}{*}{$\begin{array}{c}5.189 \\
(0.075)\end{array}$} \\
\hline & & No & $20(95 \%)$ & $227(73.9 \%)$ & $291(77 \%)$ & \\
\hline & \multirow{2}{*}{$\begin{array}{l}\text { Having difficulty relaxing and } \\
\text { quieting your mind }\end{array}$} & Yes & $2(9.5 \%)$ & $107(34.9 \%)$ & $114(30.2 \%)$ & \multirow{2}{*}{$\begin{array}{c}6.603 \\
\left(0.037^{*}\right)\end{array}$} \\
\hline & & No & $19(90.5 \%)$ & $200(65.1 \%)$ & $264(69.8 \%)$ & \\
\hline & \multirow{2}{*}{$\begin{array}{l}\text { Feeling bad about yourself } \\
\text { (low self-esteem), lonely, } \\
\text { worthless, and depressed. }\end{array}$} & Yes & $2(9.5 \%)$ & $122(39.7 \%)$ & $127(33.6 \%)$ & \multirow{2}{*}{$\begin{array}{c}9.188 \\
(0.010 *)\end{array}$} \\
\hline & & No & $19(90.5 \%)$ & $185(60.3 \%)$ & $251(66.4 \%)$ & \\
\hline & \multirow{2}{*}{ Avoiding others } & Yes & $2(9.5 \%)$ & $89(29 \%)$ & $110(29.1 \%)$ & \multirow{2}{*}{$\begin{array}{c}3.816 \\
(0.148) \\
\end{array}$} \\
\hline & & No & $19(90.5 \%)$ & $218(71 \%)$ & $268(70.9 \%)$ & \\
\hline & \multirow{2}{*}{ None of above } & Yes & $11(52.4 \%)$ & $53(17.3 \%)$ & $38(10.1 \%)$ & \multirow{2}{*}{$\begin{array}{c}32.32 \\
(<0.001 * *) \\
\end{array}$} \\
\hline & & No & $10(47.6 \%$ & $254(82.7 \%)$ & $340(89.9 \%)$ & \\
\hline \multirow{12}{*}{ 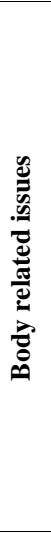 } & \multirow{2}{*}{ Low energy } & Yes & $4(19 \%)$ & $153(49.8 \%)$ & $202(53.4 \%)$ & \multirow{2}{*}{$\begin{array}{c}9.638 \\
(0.008 *) \\
\end{array}$} \\
\hline & & No & $17(81 \%)$ & $154(50.2 \%)$ & $176(46.6 \%)$ & \\
\hline & \multirow{2}{*}{ Headaches } & Yes & $1(4.8 \%)$ & $103(33.6 \%)$ & $130(34.4 \%)$ & \multirow{2}{*}{$\begin{array}{c}7.923 \\
\left(0.019^{*}\right) \\
\end{array}$} \\
\hline & & No & $20(95.2 \%)$ & $204(66.4 \%)$ & $248(65.6 \%)$ & \\
\hline & & Yes & $2(9.5 \%)$ & $97(31.6 \%)$ & $112(29.6 \%)$ & 4.595 \\
\hline & Insomnia & No & $19(90.5 \%)$ & $210(68.4 \%)$ & $266(70.4 \%)$ & $(0.100)$ \\
\hline & Dry mouth and difficulty & Yes & $0(0 \%)$ & $0(0 \%)$ & $0(0 \%)$ & - \\
\hline & swallowing & No & $21(100 \%)$ & $307(100 \%)$ & $378(100 \%)$ & -- \\
\hline & & Yes & $0(0 \%)$ & $44(14.3 \%)$ & $38(10.1 \%)$ & 5.866 \\
\hline & Clenched jaw and grinding teeth & No & $21(100 \%)$ & $263(85.7 \%)$ & $340(89.9 \%)$ & $(0.053)$ \\
\hline & None of ahove & Yes & $11(52.4 \%)$ & $66(21.5 \%)$ & $66(17.5 \%)$ & 15.40 \\
\hline & None of above & No & $10(47.6 \%$ & $241(78.5 \%)$ & $312(82.5 \%)$ & $(<0.001 * *)$ \\
\hline & dry mouth and difficulty & Yes & $0(0 \%)$ & $0(0 \%)$ & $0(0 \%)$ & \\
\hline & swallowing & No & $21(100 \%)$ & $307(100 \%)$ & $378(100 \%)$ & -- \\
\hline & Constant wrorrvino & Yes & $1(4.8 \%)$ & $109(35.5 \%)$ & $114(30.2 \%)$ & 9.501 \\
\hline & Constant worrying & No & $20(95.2 \%)$ & $198(64.5 \%)$ & $264(69.8 \%)$ & $(0.009 *)$ \\
\hline$\stackrel{\underline{m}}{\underline{\underline{m}}}$ & & Yes & $1(4.8 \%)$ & $107(34.9 \%)$ & $105(27.8 \%)$ & 10.658 \\
\hline$\ddot{n}$ & Racing thoughts & No & $20(95.2 \%)$ & $200(65.1 \%)$ & $273(72.2 \%)$ & $\left(0.005^{*}\right)$ \\
\hline 荥 & Forgetfulness and & Yes & $4(19 \%)$ & $161(52.4 \%)$ & $207(54.8 \%)$ & 10.193 \\
\hline$\Xi$ & disorganization & No & $17(81 \%)$ & $146(47.6 \%)$ & $171(45.2 \%)$ & $(0.006 *)$ \\
\hline$\stackrel{\varrho}{=}$ & Inghility to focus & Yes & $1(4.8 \%)$ & $61(19.9 \%)$ & $59(15.6 \%)$ & 4.501 \\
\hline$\tilde{\theta}^{50}$ & Mabiluy to jocus & No & $20(95.2 \%)$ & $246(80.1 \%)$ & $319(84.4 \%)$ & $(0.105)$ \\
\hline & Being pessimistic or seeing only & Yes & $12(57.1 \%)$ & $61(19.9 \%)$ & $60(15.9 \%)$ & 22.540 \\
\hline & the negative side & No & $9(42.9 \%)$ & $246(80.1 \%)$ & $318(84.1 \%)$ & $<0.001 * *$ \\
\hline & I $f$ & Yes & $5(23.8 \%)$ & $163(53.1 \%)$ & $198(52.4 \%)$ & 6.84 \\
\hline & None of above & No & $16(76.2 \%)$ & $144(46.9 \%)$ & $180(47.6 \%)$ & $(0.033 *)$ \\
\hline & Changes in appetite & Yes & $2(9.5 \%)$ & $96(31.3 \%)$ & $127(33.6 \%)$ & 5.400 \\
\hline & $\begin{array}{c}\text { either not eating or eating too } \\
\text { much }\end{array}$ & No & $19(90.5 \%)$ & $211(68.7 \%)$ & $251(66.4 \%)$ & $(0.067)$ \\
\hline & Fooling anorv & Yes & $3(14.3 \%)$ & $140(45.6 \%)$ & $136(35 \%)$ & 12.330 \\
\hline$\underline{\underline{E}}$ & Feenng angry & No & $18(85.7 \%)$ & $167(54.4 \%)$ & $242(64 \%)$ & $(0.002 *)$ \\
\hline$\stackrel{5}{=}$ & Procrastinating and avoiding & Yes & $0(0 \%)$ & $15(4.9 \%)$ & $9(2.4 \%)$ & 3.999 \\
\hline$\frac{\vec{\omega}}{\pi}$ & responsibilities & No & $21(100 \%)$ & $292(95.1 \%)$ & $369(97.6 \%)$ & $(0.135)$ \\
\hline $\bar{D}$ & Increased use of alcohol. & Yes & $1(4.8 \%)$ & $44(14.3 \%)$ & $35(9.3 \%)$ & 5.269 \\
\hline$\overline{\bar{z}}$ & drugs, or cigarettes & No & $20(95.2 \%)$ & $263(85.7 \%)$ & $343(90.7 \%)$ & $(0.072)$ \\
\hline صَّ & Exhibiting more nervous & Yes & $0(0 \%)$ & $0(0 \%)$ & $0(0 \%)$ & \\
\hline & $\begin{array}{l}\text { behaviors such as nail biting, } \\
\text { fidgeting, pacing and. }\end{array}$ & No & $21(100 \%)$ & $307(100 \%)$ & $378(100 \%)$ & -- \\
\hline & None of the ahove & Yes & $0(0 \%)$ & $0(0 \%)$ & $0(0 \%)$ & 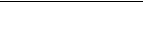 \\
\hline & None of the above & No & $21(100 \%)$ & $307(100 \%)$ & $378(100 \%)$ & -- \\
\hline
\end{tabular}

** Highly Significant

*Significant 
A systematic review showed that majority health workers are going through anxiety state, insomnia and depression [35]. A decade ago, it was predicted, that outbreak of such pandemics (Severe Acute Respiratory Syndrome) SARS, will cause health care workers to go into such state [36]. A recent study showed increased stress level of dentists due to coronavirus disease. Dentists are afraid to work in proximity of infected patients, transmission of disease to their families, increased cost of the treatment, getting quarantine phobia, fear of discrimination and death. Due to this, many dentists had closed down their practices, as the situation has worsened globally [35]. Excessive information through media has negatively influenced psychological health of health care workers as well as general public [37]. Social and economic instability has resulted. Health care workers are in need of special mental health care system to cope with psychological effects of COVID-19 pandemic [38]. Loss of self-control after stress exposure can lead to drug addiction, drinking, smoking and other maladaptive behaviors [39]. This mandates robust shift of mental health clinical therapy to digital therapy [40]. During this lockdown, stressed dental students may benefit from this e-health technology. Educational institutes should show resilience and empathy to adopt such technology for improvement in times of such crisis. However, lack of prior training of practitioners as well as patients, telehealth can reduce the outcome of treatment [41].

The limitations of this study were the lack of evaluation of self-control as well as lack of record of ethnic variations of students. Both of these can modify the response to stresses. A detailed appraisal of their clinical presentation may also help in further evaluation of their mental conditions.

\section{RECOMMENDATIONS}

In light of the results obtained through our study, it is generally recommended for all educational institutes to initiate a robust mental health care program for dental students, to deal with such situations. This program may involve designated counselling cells for routine psychological health evaluation of students. In addition, it is crucial for world wide universities as well as Pakistan Medical and Dental Council to promote and acknowledge flexible, blended learning (face to face plus distance learning) courses/degrees. This may result in time efficient curriculums useful in such calamities, like COVID-19 pandemic, without jeopardizing the educational standards.

\section{CONCLUSION}

The following conclusions were drawn from this study,

1. Majority of Pakistani dental students are suffering from moderate to high stress levels. Such students are mostly present in provinces with a higher number of COVID-19 affected reported cases,

2. There are considerable effects on emotional, physical, cognitive and behavioral states of Pakistani dental students due to the spread COVID-19 disease.

\section{ACKNOWLEDGMENT}

All authors gave final approval and agree to be accountable for all aspects of the work.

All authors confirm that this study did not receive any grant or fund from a public, commercial source, or not-forprofit firm, or from a contributors' institution. All authors abide by the International Committee of Medical Journal Editors guidelines for the Ethical Considerations in the Conduct and Report of Research

We acknowledge the cooperation of administration of all institutes, for participation in this study.

\section{DISCLAIMER}

There are no potential conflicts of interest with respect to the authorship, funding and/or publication of this article.

\section{REFERENCES}

[1] Chen J. Pathogenicity and transmissibility of 2019-nCoV-A quick overview and comparison with other emerging viruses. Microbes Infect. 2020;22(2):69-71

[2] CDC. Influenza (Flu): Weekly U.S. Influenza Surveillance Report 2020 [Available from: https://www.cdc.gov/flu/weekly/index.htm.

[3] Backer JA, Klinkenberg D, Wallinga J. Incubation period of 2019 novel coronavirus (2019-nCoV) infections among travellers from Wuhan, China, 20-28 January 2020. Eurosurveillance. 2020;25(5):2000062

[4] Guan W-j, Ni Z-y, Hu Y, Liang W-h, Ou C-q, He J-x, et al. Clinical Characteristics of Coronavirus Disease 2019 in China. New England Journal of Medicine. 2020;382(18):1708-20.

[5] Zhang L, Liu Y. Potential interventions for novel coronavirus in China: A systematic review. Journal of Medical Virology. 2020;92(5):479-90.

[6] Merriam-Webster. Lockdown | Definition of Lockdown 2020 [Available from: https://www.merriamwebster.com/dictionary/lockdown.

[7] Ahmed MA, Jouhar R, Ahmed N, Adnan S, Aftab M, Zafar MS, et al. Fear and Practice Modifications among Dentists to Combat Novel Coronavirus Disease (COVID-19) Outbreak. International Journal of Environmental Research and Public Health. 2020;17(8):2821.

[8] Sahu P. Closure of Universities Due to Coronavirus Disease 2019 (COVID-19): Impact on Education and Mental Health of Students and Academic Staff. Cureus. 2020;12(4):e7541

[9] Ahmad FA, Karimi AA, Alboloushi NA, AL-Omari QD, AlSairafi FJ Qudeimat MA. Stress Level of Dental and Medical Students: Comparison of Effects of a Subject-Based Curriculum versus a CaseBased Integrated Curriculum. Journal of Dental Education. 2017;81(5):534-44.

[10] Heath JR, Macfarlane TV, Umar MS. Perceived sources of stress in dental students. Dent Update. 1999;26(3):94-8, 100

[11] Mariotti A. The effects of chronic stress on health: new insights into the molecular mechanisms of brain-body communication. Future Sci OA. 2015;1(3):FSO23-FSO

[12] T S. Perceived sources of stress in the academic environment in undergraduate dental students [Thesis]: Univerity Institute of Public Health, The University of Lahore.; 2015.

[13] Basudan S, Binanzan N, Alhassan A. Depression, anxiety and stress in dental students. Int J Med Educ. 2017;8:179-86.

[14] Collin V, Toon M, O'Selmo E, Reynolds L, Whitehead P. A survey of stress, burnout and well-being in UK dentists. British Dental Journal. 2019;226(1):40-9

[15] Ishaque MY, Farid H, Yasmeen S. Perceived causes of stress among dental undergraduates at army medical college, Rawalpindi. Pakistan Oral \& Dental Journal. 2015;35(1).

[16] Hewitt PL, Flett GL, Mosher SW. The Perceived Stress Scale: Factor structure and relation to depression symptoms in a psychiatric sample. Journal of Psychopathology and Behavioral Assessment. 1992;14(3):247-57.

[17] Cohen S, Kamarck T, Mermelstein R. A Global Measure of Perceived Stress. Journal of Health and Social Behavior. 1983;24(4):385-96. 
[18] Shah M, Hasan S, Malik S, Sreeramareddy CT. Perceived Stress, Sources and Severity of Stress among medical undergraduates in a Pakistani Medical School. BMC Medical Education. 2010;10(1):2.

[19] Stress symptoms [Available from: http://umash.umn.edu/wpcontent/uploads/2019/01/Stress-Symptoms.pdf.

[20] System TS. Sample Size Calculator 2012 [Available from: https://www.surveysystem.com/sscalc.htm.

[21] Khan NI. VALIDITY ASSESSMENT OF COPING STYLES SCALE (CSS). Pakistan journal of psychology. 2015;46.

[22] Roberti JW, Harrington LN, Storch EA. Further Psychometric Support for the 10-Item Version of the Perceived Stress Scale. Journal of College Counseling. 2006;9(2):135-47.

[23] Shaikh B, Kahloon A, Kazmi M, Khalid H, Nawaz K, Khan N, et al Students, stress and coping strategies: a case of Pakistani medica school. Education for Health. 2004;17(3):346-53.

[24] Zhai L, Zhang Y, Zhang D. Sedentary behaviour and the risk of depression: a meta-analysis. Br J Sports Med. 2015;49(11):705-9.

[25] Lee E-H. Review of the Psychometric Evidence of the Perceived Stress Scale. Asian Nursing Research. 2012;6(4):121-7.

[26] Lavoie JAA, Douglas KS. The Perceived Stress Scale: Evaluating Configural, Metric and Scalar Invariance across Mental Health Status and Gender. Journal of Psychopathology and Behavioral Assessment. 2012;34(1):48-57.

[27] Denovan A, Dagnall N, Dhingra K, Grogan S. Evaluating the Perceived Stress Scale among UK university students: implications for stress measurement and management. Studies in Higher Education. 2019;44(1):120-33.

[28] Ramirez MT, Hernandez RL. Factor structure of the Perceived Stress Scale (PSS) in a sample from Mexico. Span J Psychol 2007;10(1):199-206.

[29] Information about COVID-19/ Coronavirus in Pakistan [16/05/2020]. Available from: http://covid.gov.pk/.

[30] Kang L, Li Y, Hu S, Chen M, Yang C, Yang BX, et al. The menta health of medical workers in Wuhan, China dealing with the 2019 novel coronavirus. The Lancet Psychiatry. 2020;7(3):e14.

[31] Cai H, Tu B, Ma J, Chen L, Fu L, Jiang Y, et al. Psychological Impact and Coping Strategies of Frontline Medical Staff in Hunan Between January and March 2020 During the Outbreak of Coronavirus Disease 2019 (COVID-19) in Hubei, China. Med Sci Monit. 2020;26:e924171.

[32] Arnsten AFT. Stress signalling pathways that impair prefrontal cortex structure and function. Nat Rev Neurosci. 2009;10(6):410-22.

[33] Buschman TJ, Miller EK. Top-down versus bottom-up control of attention in the prefrontal and posterior parietal cortices. Science. 2007;315(5820):1860-2.

[34] Coenen A, Flik G. Effects of stress on behavior and sleep. Cortisol: a stress hormone and a wake hormone? Праці наукового товариства ім Шевченка Медичні науки. 2017(49):53-7.

[35] Spoorthy MS, Pratapa SK, Mahant S. Mental health problems faced by healthcare workers due to the COVID-19 pandemic-A review. Asian Journal of Psychiatry. 2020;51:102119.

[36] Wu KK, Chan SK, Ma TM. Posttraumatic stress after SARS. Emerg Infect Dis. 2005;11(8):1297-300

[37] Cai Q, Yang M, Liu D, Chen J, Shu D, Xia J, et al. Experimental Treatment with Favipiravir for COVID-19: An Open-Label Control Study. Engineering. 2020.

[38] Duan L, Zhu G. Psychological interventions for people affected by the COVID-19 epidemic. The Lancet Psychiatry. 2020;7(4):300-2

[39] Li C-sR, Sinha R. Inhibitory control and emotional stress regulation: neuroimaging evidence for frontal-limbic dysfunction in psychostimulant addiction. Neurosci Biobehav Rev. 2008;32(3):581-97.

[40] Wind TR, Rijkeboer M, Andersson G, Riper H. The COVID-19 pandemic: The 'black swan' for mental health care and a turning point for e-health. Internet Interventions. 2020;20:100317.

[41] Rogers MA, Lemmen K, Kramer R, Mann J, Chopra V. InternetDelivered Health Interventions That Work: Systematic Review of Meta-Analyses and Evaluation of Website Availability. J Med Internet Res. 2017;19(3):e90. 